\title{
Potential Habitat and Carrying Capacity of Endangered San Joaquin Kit Foxes in an Urban Environment: Implications for Conservation and Recovery
}

\section{Brian Cypher ( $\sim$ bcypher@esrp.csustan.edu )}

California State University-Stanislaus https://orcid.org/0000-0002-7349-545X

Nicole A. Deatherage

California State University Stanislaus

Tory L. Westall

California State University Stanislaus

Erica C. Kelly

California State University Stanislaus

Scott E. Phillips

California State University Stanislaus

\section{Research Article}

Keywords: California, Carrying capacity, Endangered species, Habitat suitability, Kit fox, Urban environment, Vulpes macrotis mutica

Posted Date: October 29th, 2021

DOI: https://doi.org/10.21203/rs.3.rs-833974/v1

License: (c) (i) This work is licensed under a Creative Commons Attribution 4.0 International License.

Read Full License 


\section{Abstract}

The San Joaquin kit fox (Vulpes macrotis mutica; SJKF) is federally endangered due to profound habitat loss. A population of SJKF occurs in the urban environment in the city of Bakersfield, California, and may be important for SJKF conservation. We conducted a systematic survey using automated cameras stations and occupancy analysis to identify suitable habitat for SJKF in Bakersfield and to estimate a conceptual carrying capacity in the urban environment. We identified high, medium, and low suitability habitat totaling $121 \mathrm{~km}^{2}, 196 \mathrm{~km}^{2}$, and $40 \mathrm{~km}^{2}$, respectively. Based on a mean home range size of 0.78 $\mathrm{km}^{2}$ and an assumption of two adults in high suitability home ranges and one adult in medium suitability ranges, we estimated the adult carrying capacity in Bakersfield to be 561 foxes. This estimate seems plausible as the number of adult SJKF in Bakersfield was estimated to be 381 in 2015, and the number of foxes already had been reduced by a sarcoptic mange epidemic that began two years earlier. A carrying capacity of 561 adults would increase the estimated range-wide carrying capacity by as much as $38 \%$. Density estimates derived for the urban SJKF population based on the carrying capacity $\left(1.57 / \mathrm{km}^{2}\right)$ and home range size $\left(2.56 / \mathrm{km}^{2}\right)$ were higher than estimates for foxes in natural habitats. The urban SJKF population in Bakersfield is substantial and therefore could contribute significantly to conservation and recovery efforts for SJKF. Given our results, a potential conservation strategy may be to encourage or even establish additional urban SJKF populations.

\section{Introduction}

The San Joaquin kit fox (Vulpes macrotis mutica; SJKF) is endemic to the San Joaquin Desert region in central California, USA (U.S. Fish and Wildlife Service [USFWS] 1998; Germano et al. 2011). This small canid (ca. 2-3 kg) once was widely distributed in arid shrubland and grassland habitats in the San Joaquin Valley, Carrizo Plain, Panoche Valley, and Cuyama Valley with intermittent populations occurring in the Salinas Valley (USFWS 1998; Cypher et al. 2013). Considerable habitat within the range of the SJKF has been converted to agricultural, urban, and industrial uses (Kelly et al. 2005; Cypher et al. 2013). Due to this profound habitat loss, the SJKF was listed as federally Endangered in 1967 and California Threatened in 1980 (USFWS 1998).

Habitat loss is still occurring within the range of the SJKF and continues to constitute a significant threat (USFWS 2010). Interestingly, although urban development is one of the primary causes of habitat destruction in the San Joaquin Desert, SJKF commonly occur in the city of Bakersfield and also are present in the small towns of Taft and Coalinga (Cypher 2010).

SJKF occur throughout Bakersfield and are commonly observed using a diversity of land uses within the urban environment, particularly campuses (e.g., schools, churches), maintained open space (e.g., parks, golf courses), low to medium density residential areas (e.g., apartment homes or nursing homes), and commercial areas (Frost 2005; Cypher 2010; Deatherage et al. 2021). Urban SJKF avoid areas with high densities of paved roads due to increased disturbance and mortality risk (Bjurlin et al. 2005; Deatherage et al. 2021). The Bakersfield SJKF population is demographically robust exhibiting high survival and 
reproductive rates (Cypher 2010). Thus, this population is substantial and potentially could contribute to the conservation and recovery of the SJKF (Cypher 2010; Cypher and Van Horn Job 2012). However, the number of SJKF or the amount of suitable habitat available in Bakersfield have not been quantitatively estimated.

Our objectives were to (1) estimate the amount of suitable habitat for SJKF in Bakersfield, (2) estimate the potential carrying capacity for SJKF in the urban environment, (3) estimate actual abundance and density of SJKF in Bakersfield, and (4) compare the density estimates between urban and non-urban SJKF populations.

\section{Methods}

\section{Study area}

Bakersfield is located in Kern County in the southern San Joaquin Valley in central California, USA. The city currently has an area of $392 \mathrm{~km}^{2}$ and current human population is ca. 390,000 . Average elevation is $124 \mathrm{~m}$, with little topographic variation. Climate is characterized by hot, dry summers and cool winters with infrequent precipitation in the form of rain. Average high and low temperatures are $13.7 \mathrm{C}$ and $3.9 \mathrm{C}$ in December and 36.2 C and 21.4 C in July. Mean annual precipitation is $164 \mathrm{~mm}$ (National Oceanic and Atmospheric Administration 2020). Bakersfield is bounded by occupied SJKF habitat to the northeast and southwest (Cypher et al. 2013) with irrigated agriculture bordering the city elsewhere.

\section{Habitat attributes}

To assess habitat attribute preferences by SJKF in Bakersfield, we established a sampling grid over the city consisting of $3571-\mathrm{km}^{2}$ grid cells that contained at least $50 \%$ human development. We used satellite imagery to quantify the occurrence of 13 urban landscape attributes in each of the cells. The attributes were those identified in Deatherage et al. (2021) as being important for urban SJKF and are described in Table 1. To estimate land use composition and index feature abundance, we superimposed a point grid (10×10 grid, 100 points total) over each cell in Google Earth Pro. We used Google Earth Pro imagery dated 26 April 2018 at an eye altitude of 300-m above ground level to characterize grid points. We characterized each point by the attribute that best described the location of the point (i.e., the terrestrial land use type on which the majority of the point was located or closest to), and recorded if the point fell on a mature tree. If a point appeared to fall equally on two different landscape types, we split the proportion of the point equally between the attributes (0.5:0.5). The proportion of points in each land use in a given cell was considered to approximate the proportion of that cell consisting of that land use. Water bodies generally were small and were recorded as present or absent for each cell.

We tested for pairwise correlations between landscape attributes using Spearman's Rank tests and adjusted the resulting $P$ values using the method proposed by Legendre and Legendre (1998) to account for the inflated risk of a type I statistical error when running multiple tests. Correlations were completed 
in Minitab 19 statistical software (Minitab LLC, State College, PA) and an a-level of 0.05 was used to determine statistical significance.

\section{Grid use by SJKF}

We conducted surveys for SJKF in a sample of grid cells using camera stations. We used the randomization function in Excel 2010 (Microsoft, Redmond WA) to randomly choose 120 grid cells to potentially sample from the 357 available cells. Within each selected grid cell, we then identified locations (1) that were accessible to kit foxes and (2) where the risk of camera theft was low (i.e., locations with restricted public access or where a camera could be placed in a cryptic location). Kit foxes are able to access most locations within the urban landscape, but generally avoid high-density residential areas due to the presence of fences, walls, dogs, and high levels of disturbance (Frost 2005; Cypher 2010). Consequently, most camera stations were placed in locations such as school campuses, city or county storm water drainage basins, municipal facilities, churches, golf courses, private businesses (with owner permission), and undeveloped parcels.

Within each sampled grid cell, we employed an automated camera station design and methodology developed specifically to survey for kit foxes and other sympatric carnivores (Westall and Cypher 2017). We used Cuddeback Digital Black Flash IR cameras (Model 1255, Non Typical Inc., Green Bay, WI) that employ a "black flash" infrared LED flash that creates almost no light visible to humans and that take high-resolution images (20 megapixels). We secured the cameras to 1.2-m U-posts using zip-ties. At some locations where cameras might be discovered by the public, we placed the cameras in protective cases ("CuddeSafe" Model 3327, Non Typical Inc., Green Bay, WI) that were then secured with a cable lock to fences, trees, or other immobile structures. To attract foxes, we placed several drops of a scent lure (Carman's Canine Call Lure, New Milford, PA) in front of the camera and on surrounding vegetation. We also staked a 163-ml can of cat food to the ground approximately $2 \mathrm{~m}$ in front of each camera using 30$\mathrm{cm}$ nails. The cat food cans were perforated to allow scent to void but limit access to the food. The staked cat food cans functioned as a further attractant for foxes and also caused them to remain in the camera's field of view for an extended period as foxes attempted to access the food in the cans.

The average diameter of a kit fox home range in Bakersfield is $1 \mathrm{~km}$, based on an estimated mean home range size of $0.78 \mathrm{~km}^{2}$ (CSUS Endangered Species Recovery Program, unpublished data). Camera station locations typically were separated by at least $1 \mathrm{~km}$ to reduce the probability of a given kit fox being detected at more than one station. Because $97.1 \%$ of kit foxes are typically detected at camera stations within six nights (Westall and Cypher 2017), cameras were deployed at each location for seven nights. Images were then downloaded from each camera and examined for visits by kit foxes each of the seven days. Because kit foxes are primarily nocturnal, each new day started at 1200 . The sampled grid cells with and without kit fox detections were recorded. This survey was conducted each summer from 2015 to 2019. However, only the 2015 results were used for the habitat analyses because an epidemic of sarcoptic mange (Cypher et al. 2017) reduced the abundance of SJKF in each subsequent year (see 
population estimation results below), and these latter results were less reflective of actual grid cell use by the foxes.

\section{Suitable habitat}

The quantity of suitable habitat for SJKF in Bakersfield was estimated using occupancy modeling based on the 2015 camera station survey results in conjunction with habitat attributes measured in each of the $1-\mathrm{km}^{2}$ cells. We used kit fox detection histories in single-species, single-season occupancy models in program PRESENCE (Hines 2006) to produce probability estimates of kit fox occupancy $(\psi)$ in relation to landscape covariates while accounting for detection uncertainty (MacKenzie et al. 2018). We assumed no unmodeled heterogeneity in our data and that occupancy state in each cell did not change over the seven days of the survey. To develop our candidate models, we fit models first with no occupancy covariates (null model), followed by a global model including all covariates considered most likely to influence kit fox occupancy, then with each covariate individually, and finally with pairwise additive combinations of covariates following three a priori modeling categories representing general landscapes that may influence kit fox occupancy: campuses or campus-like landscapes, roads, and commercial or commercial-like landscapes. We allowed detection parameters to vary for each survey day. Covariates that were strongly correlated at $r_{s}> \pm 0.60$ were not included in the same multi-covariate model (Burnham and Anderson 2002).

We calculated a Pearson $\chi^{2}$ goodness of fit statistic and an overdispersion factor, , in PRESENCE to evaluate the fit of our global model with 1,000 bootstraps (Burnham and Anderson 2002). We assessed goodness of fit significance at an a-level of 0.05 and considered $>1$ as overdispersion in models (Burnham and Anderson 2002). We used Akaike's Information Criterion (AIC) and beta ( $\beta$ ) estimates to evaluate models and used quasi-corrected AIC (QAIC) to adjust for poor model fit and overdispersion (Burnham and Anderson 2002). We considered sample size/maximum number of model parameters $(K)$ $<40$ as small, and used QAIC $C_{c}$ to further adjust for small sample sizes (Burnham and Anderson 2002). We derived a model confidence set based on QAIC $_{c}$ weights $(w)$ of the most supported predictors of kit fox occupancy and calculated model-averaged estimates of occupancy and detection parameters as well as $95 \%$ confidence intervals across multiple competing models in Excel 2019 (Burnham and Anderson 2002).

We calculated a model-averaged estimate of kit fox occupancy in each $1-\mathrm{km}^{2}$ cell in PRESENCE. We used the Natural Breaks function in ArcGIS Desktop 10.6 (ESRI, West Redlands, CA) to classify kit fox occupancy probability values into three categories of habitat suitability: high, medium, and low. This function uses the Jenks Natural Breaks algorithm to identify breaks in the data that best groups similar values together and maximizes the differences between classes (de Smith et al. 2021). We summed the number of cells in each classification to determine the total area of each habitat category within the study area. We mapped these results to display the distribution of the habitat categories across the city. Finally, we created a more fine-scale representation of SJKF habitat suitability in Bakersfield. We used the Polygon to Raster conversion tool in ArcGIS to create a raster with a cell size $100 \mathrm{~m}^{2}(10 \times 10 \mathrm{~m})$. This 
cell size approximates the area that was characterized by each grid point when measuring the habitat attributes. The ArcGIS Spatial Analyst Focal Statistics tool to recalculate the SJKF occupancy probability for each $100-\mathrm{m}^{2}$ cell. For each cell, we calculated its value as the mean of cell values in a 1,000 $1,000-\mathrm{m}$ rectangular window around the cell. In this final map, each suitability category was divided into two to produce a representation that better depicts the uncertainty in precise boundaries between the suitability categories.

\section{Carrying capacity and population estimation}

We estimated a conceptual carrying capacity for SJKF in Bakersfield. We calculated an estimate two ways using the suitable habitat quantities derived from the occupancy analysis. For one estimate, we divided the quantity of highly suitable habitat by $0.78 \mathrm{~km}^{2}$, which is the average home range size for kit foxes in Bakersfield (CSUS Endangered Species Recovery Program, unpublished data). This provided an estimate of the number of home ranges that potentially could be present in Bakersfield. Each social group occupying a home range minimally consists of an adult male and an adult female (Cypher 2010). Therefore, we multiplied the number of home ranges by two to produce an estimate of adult carrying capacity.

For the second estimate, we conducted the calculation above. In addition, we divided the quantity of medium quality habitat by the average home range size to estimate the number of home ranges in this habitat. However, because this was lower quality habitat, we assumed that the number of foxes might be lower (e.g., either foxes require more area than the average home range size, not all areas were occupied, not all areas might have a pair of adult foxes). Thus, we multiplied the number of home ranges by one. The resulting number was added to that derived for the high quality habitat to produce a potential carrying capacity of adult foxes.

To assess the plausibility of the carrying capacity estimates, we estimated the number of SJKF in Bakersfield each year from 2015 to 2019 using the systematic camera station survey described above. We conservatively estimated the number of individuals based on the presence of multiple animals in a single image or distinctive physical features on individuals (e.g., reproductive structures, deformities such as notched ear or shortened tail, eartags or radiocollars, sarcoptic mange symptoms). We then tallied the number of grid cells with kit foxes and the total estimated number of kit foxes detected. Finally, we estimated the total number of SJKF in Bakersfield using a simple proportional equation:

$$
\frac{\text { observed foxes }}{\text { sampled cells }}=\frac{\text { total foxes }}{\text { total cells }}
$$

\section{Results}

\section{Suitable habitat}


Among the habitat attributes, only the pairwise correlation between OROW and Com was significant $\left(r_{s}=\right.$ $0.61, t=14.62, \mathrm{df}=355, P($ corrected $)<0.001)$ while the remaining 65 pairwise correlations were not significant $\left(r_{s}<0.60\right)$. We developed 92 candidate occupancy models including 13 models with individual covariates, the null model, and the global model. The global model included the CollectorR, ArterialR, HighwayR, High, and Camp covariates, resulting in $k=14$ parameters and the use of $\mathrm{AlC}_{\mathrm{c}}$. For the three $a$ priori covariate categories, 24 models represented campuses or campus-like landscapes, 44 represented roads, and nine represented commercial or commercial-like landscapes. The goodness of fit test on the global model indicated poor fit and overdispersion $\left(\chi^{2}=320.78, P<0.0001,=2.68\right)$ so we adjusted the model results to $\mathrm{QAIC}_{\mathrm{c}}$ using $=2.68$.

We considered models with $\triangle \mathrm{QAIC}_{\mathrm{c}}<2.70$ to be supported predictors of kit fox occupancy (Table 2 ). The cumulative $w$ for all 16 supported models was 0.33 , resulting in a $33 \%$ confidence set (Table 2 ). The null model was the most supported model based on QAIC $_{c}$, followed by High as an individual covariate (Table 2). An additive model with CollectorR+PGS was the lowest ranking supported model and the global model was the lowest ranking of all 92 models (Table 2). High was the most represented covariate in the confidence set, appearing in seven of the 16 supported models, followed by PGS which appeared in four of the 16 models (Table 2). The model-averaged occupancy $\beta$ estimates resulted in High being the most supported covariate across the confidence set, with all other $\beta 95 \%$ confidence intervals slightly crossing 0 (Table 3). High had a negative effect on kit fox $\psi$ (Fig. 2), as did CollectorR and ArterialR, while PGS, $L M D R$, Trees, and Camp all had a slight positive effect on kit fox $\psi$ (Table 3 ).

The model-averaged $\psi$ estimates in each cell resulted in a minimum kit fox occupancy probability of 0.13 and a maximum probability of 0.25 across all cells (Table 4). The lowest averaged $\psi$ of all cells was estimated for the cell with highest percentage of High (12\% of the cell), which included intersections between two major highways and between a highway and arterial road. This cell also had no PGS, LMDR, or Camp. The highest averaged $\psi$ of all cells was estimated for a cell that was dominated by $L M D R(27 \%$ of the cell), had five different campuses or parks in it, and had no highways. The medium habitat classification was defined by the smallest range of $\psi$ values but contained the largest number of cells (Table 4, Fig. 3). Conversely, poor habitat was defined by the largest range of $\psi$ values but contained the fewest number of cells (Table 4, Fig. 3). Based on the fine-scaled map, kit fox $\psi$ was highest in areas with PGS, LMDR, and Camp, and lowest in areas with High (Fig. 4).

\section{Carrying capacity and population estimates}

The estimated $121 \mathrm{~km}^{2}$ of high quality habitat conceivably could support 155 urban SJKF home ranges. Assuming that a pair of adult kit foxes could occupy each home range, the estimated carrying capacity of the high quality habitat would be 310 adult foxes. The estimated $121 \mathrm{~km}^{2}$ of high quality habitat and $196 \mathrm{~km}^{2}$ of medium quality habitat potentially could support 406 urban kit fox home ranges. Assuming that a pair of adult kit foxes could occupy each home range in the high quality habitat and that one adult kit fox on average could occupy each home range in the medium quality habitat, the estimated carrying 
capacity of the two habitats combined would be 561 adult foxes. This constitutes a conceptual carrying capacity for adult San Joaquin kit foxes in Bakersfield.

The number of adult kit foxes observed during the camera station surveys ranged from 112 in 2015 to 33 in 2019 (Table 5). City-wide population estimates derived using the ratio estimator ranged from 381 adult kit foxes in 2015 to 107 in 2019 (Table 5). The total number of foxes observed during the surveys ranged from 129 in 2015 to 43 in 2019 resulting in city-wide total population estimates ranging from 439 in 2015 to 140 in 2019 (Table 5).

\section{Discussion}

The presence of SJKF in the urban environment within Bakersfield is not necessarily surprising. Canids in general exhibit high ecological and behavioral plasticity (Johnson et al. 1996; Macdonald and Reynolds 2004). This allows them to adapt to novel situations, including the use of human-derived resources and the occupation of anthropogenically altered environments, such as urban areas. As prime examples, both coyotes (Canis latrans) and red foxes ( $V$. vulpes) have expanded their ranges significantly in North America in response to anthropogenic landscape and ecological changes (Voight 1987; Voigt and Berg 1987; Gese and Bekoff 2004; Macdonald and Reynolds 2004). Both of these species also are commonly found in urban environments and frequently consume human-derived resources such as refuse, pet food, pets, crops, and livestock. Robust red fox populations also are found in numerous European cities (Soulsbury et al. 2010). Gray foxes (Urocyon cinereoargenteus) also are occurring with increasing frequency in urbanized areas, including most of the cities on the east side of the San Joaquin Valley (e.g., Turlock, Merced, Madera, Fresno, Visalia, Porterville, and Bakersfield). Interestingly, in addition to kit foxes, red foxes, gray foxes, and coyotes all occur within the Bakersfield city limits, although kit foxes are the most abundant of the species, probably because the other species require larger open spaces.

Attributes of areas used by SJKF in the urban environment were described in detail by Deatherage et al. (2021). In general, SJKF exhibit higher use of areas with campuses (e.g., schools, churches) and other open space (e.g., parks and other green spaces), and lower use of areas with high densities of paved roads, particularly larger roads with four or more lanes. Similar habitat use trends were found among urban red foxes (Soulsbury et al. 2010). In Bakersfield, the lighter colored, lower suitability areas in Figure 4 mostly align with larger, multi-lane highways with higher speeds and traffic volumes. Higher suitability areas largely align with grid cells with more open space. Based on the results of the occupancy analysis we conducted, the total area with an optimal combination of habitat attributes for SJKF in Bakersfield is considerable $\left(121 \mathrm{~km}^{2}\right)$. The total area with a less optimal combination but that still is used by kit foxes is even greater $\left(196 \mathrm{~km}^{2}\right)$. Thus, there is a substantial quantity of habitat in Bakersfield that is suitable for use by SJKF.

As a consequence of the large quantity of potentially suitable habitat, the conceptual carrying capacity for SJKF in Bakersfield also is substantial. We estimated this carrying capacity to be 310 adults in the highly suitable habitat areas, and 561 adults in the high and medium suitability habitats combined. The 
SJKF population estimates derived from the camera station surveys provide a measure of plausibility for the conceptual carrying capacity estimate. The estimates were for the years 2015 to 2019 and exhibit a consistent declining trend. However, a sarcoptic mange epidemic began among SJKF in Bakersfield in 2013 causing considerable mortality among the foxes (Cypher et al. 2017). This caused the observed decline in SJKF numbers across years. (Although the number of cases is much reduced, SJKF with mange are still being detected in Bakersfield.) The number of adult SJKF in Bakersfield was estimated to be 381 in 2015, which was two years into the epidemic. Consequently, the number of adults likely was much higher prior to the epidemic and therefore closer to the conceptual carrying capacity estimate of 561. Also, at any given point in time, it is highly unlikely that all of the available habitat would be occupied by pairs of adult SJKF simply because of annual mortality within the population (see Cypher 2010 for annual survival rates and causes of mortality among urban SJKF). For example, in the 12 months prior to the 2015 survey, 26 adult kit fox mortalities (12 from mange, 8 from vehicles, 6 from unknown causes) were opportunistically recorded in Bakersfield (CSUS Endangered Species Recovery Program unpublished data). Thus, any population estimate would naturally be lower than the conceptual carrying capacity.

The conceptual carrying capacity for SJKF in Bakersfield is substantial relative to that for the entire range of SJKF. Cypher et al. (2013) quantified suitable habitat throughout the range of the SJKF. They estimated that the available high and medium suitability habitat potentially could support 3,616 adult foxes. However, they cautioned that this was very likely an over-estimate because (1) the estimate was derived based on average home range size in high quality habitat (ranges in medium quality habitat would likely be larger and therefore this habitat would support fewer foxes per area), (2) unlike in the urban environment in Bakersfield, non-urban medium quality habitat appears to function primarily as "over flow" or dispersal habitat and no SJKF populations are known to occur in this habitat, and (3) the available habitat estimates included lands in some counties where no populations of SJKF are known to occur because the remaining habitat patches are too small. Based on the quantity of high quality habitat in the counties where resident kit foxes are known to occur (Fresno, Kern, Kings, Merced, San Luis Obispo, San Benito, San Santa Barbara, and Tulare; see Table 2 in Cypher et al. 2013), the estimated carrying capacity (based on a mean home range size of 544 ha and two adult foxes per home range) is 1,496. Thus, the available habitat in Bakersfield increases the potential range-wide carrying capacity by $38 \%$, which is substantial.

Urban habitat supports higher densities of SJKF compared to non-urban habitat. During 1981-1995 at the Naval Petroleum Reserves in the western Kern County, annual density for all foxes averaged $0.82 / \mathrm{km}^{2}$ (Cypher et al. 2000). On the Carrizo Plain in eastern San Luis Obispo County, density of all SJKF declined from $0.24 / \mathrm{km}^{2}$ in 1989 to $0.15 / \mathrm{km}^{2}$ in 1991 as a drought reduced annual prey availability (White et al. 1996). Western Kern County and the Carrizo Plain are considered "core areas" for SJKF due to the presence of large blocks of high quality habitat (USFWS 1998; Cypher et al. 2013). At Camp Roberts in northern San Luis Obispo County, mean density of all foxes in winter during $1988-1990$ was $0.74 / \mathrm{km}^{2}$ (Berry and Standley 1992). In Bakersfield, the 2015 estimates of 381 adult foxes and 439 total foxes in 
the $357-\mathrm{km}^{2}$ study area yielded density estimates of $1.07 / \mathrm{km}^{2}$ for adults and $1.23 / \mathrm{km}^{2}$ for all foxes. As described previously, SJKF abundance likely began declining in 2013 due to a sarcoptic mange epidemic and the number density of SJKF in Bakersfield may have been even higher in prior years. SJKF likely occur in higher densities in urban environments due to greater resource availability and fewer natural predators (Cypher 2010).

The conceptual range-wide carrying capacity described above would result in an adult SJKF density of $0.37 / \mathrm{km}^{2}\left(1,496\right.$ foxes in $\left.4,069 \mathrm{~km}^{2}\right)$. The conceptual carrying capacity for the urban environment in Bakersfield would result in an adult SJKF density of $1.57 / \mathrm{km}^{2}$ ( 561 foxes in $357 \mathrm{~km}^{2}$ ). One final method of comparing densities between urban and non-urban habitats is based on mean home range size. Assuming two adult foxes occupy each home range, a density estimate for a given study area can be derived by multiplying 2 times the inverse of the mean home range size on that study area. Applying this approach to results reported in several multi-year studies produces density estimates (foxes $/ \mathrm{km}^{2}$ ) of 0.30 (mean home range size of $6.7 \mathrm{~km}^{2}$ in the Lokern area in western Kern County; Spiegel and Bradbury 1992), 0.34 (mean home range size of $5.9 \mathrm{~km}^{2}$ in the Lokern area in western Kern County; Nelson et al. 2007), 0.39 (mean home range size of $5.1 \mathrm{~km}^{2}$ in northern Carrizo Plain in eastern San Luis Obispo County; Cypher et al. 2014), and 0.48 (mean home range size of $4.2 \mathrm{~km}^{2}$ in the central Carrizo Plain in eastern San Luis Obispo County; Boroski et al. 2021). Applying the same method to data from urban foxes in Bakersfield produces a density of 2.56 foxes $/ \mathrm{km}^{2}$ (mean home range size of $0.78 \mathrm{~km}^{2}$; CSUS Endangered Species Recovery Program, unpublished data).

Higher densities in urban areas has both benefits and risks. A benefit is that more foxes are supported per unit area. Larger populations generally have lower risk of extinction (Frankham et al. 2017). A risk is that the potential for disease transmission is greater. This is abundantly evident for SJKF in that to date, sarcoptic mange has only been detected among urban kit foxes in Bakersfield and the nearby city of Taft, but has not been detected in any non-urban kit foxes despite extensive surveillance (CSUS Endangered Species Recovery Program, unpublished data). The occurrence of mange and associated mortality rates were significantly higher for urban red fox populations in Illinois where home ranges were smaller and density presumably higher compared to non-urban populations (Gosselink et al. 2007). Mange rates in red foxes also increased with density in Japan (Uraguchi et al. 2014). Higher density also has been associated with higher transmission rates of rabies in urban red foxes in Australia (Marks and Bloomfield 1999) and Canada (Rosatte et al. 1990), and non-urban red foxes in northeastern Europe (Holmala and Kauhala 2006).

\section{Conclusion}

The urban habitat within the city of Bakersfield potentially can support a substantial SJKF population that could increase the range-wide population markedly. Indeed, a sizeable SJKF population already is present in Bakersfield, although abundance has been reduced in recent years due to an epidemic of sarcoptic mange among the foxes. Absent mange, this SJKF population is demographically and 
ecologically robust, and therefore has a high probability of persistence (Cypher 2010). In addition to increasing the overall abundance of SJKF, this population also increases range-wide genetic diversity, serves as a hedge against catastrophic events in the non-urban populations, and could serve as a source population for introductions of SJKF into vacant or restored habitats (Cypher 2010; Cypher and Van Horn Job 2012; Wilbert 2013). Thus, this population clearly can contribute significantly to the conservation and recovery of SJKF and warrants conservation. Furthermore, this is the only SJKF population known to be growing (again, absent mange). The city of Bakersfield is growing markedly on an annual basis and we have observed SJKF rapidly colonizing newly urbanized areas (many of which previously were agricultural lands that are not used by kit foxes (Warrick et al. 2007; Cypher et al. 2013).

A list of wildlife species that occur and even thrive in urban environments would be extensive. Thus, the presence of a given species in an urban environment generally is not remarkable. However, the urban SJKF population in Bakersfield is unique and noteworthy because the species is endangered. The occurrence of species of conservation concern in urban areas (ones that are actually using the urban environment versus remnant patches of natural lands) is rare with only a few other examples, such as key deer (Odocoileus virginianus clavium), peregrine falcons (Falco peregrinus), and western burrowing owls (Athene cunicularia hypugaea) (Adams et al. 2006). Populations of rare species in urban areas offer unique conservation opportunities as these are essentially "bonus" populations. In the case of peregrine falcons, they were introduced into a number of cities in North America and thrived resulting in the species being removed from the endangered species list in 1999 (Cade et al. 1996). Perhaps a similar strategy could be considered for SJKF. They already occur in the small cities of Taft and Coalinga, and they might thrive in other cities within the historic range of the SJKF such as Delano, Tulare, Hanford, Visalia, Fresno, Los Banos, Patterson, and possibly others. The Bakersfield population potentially could serve as a source population as SJKF are relatively abundant there with high reproductive rates and the foxes are already adapted to urban life. Additional populations should produce a concomitant reduction in extinction risk (Frankham et al. 2017) for this species.

\section{Declarations}

\section{Funding}

Funding for this project was provided by the U.S. Bureau of Reclamation's Central Valley Project Conservation Program, U.S. Fish and Wildlife Service, and the California Department of Fish and Wildlife.

\section{Conflicts of interest/Competing interests}

The authors declare no conflicts of interest.

\section{Availability of data and material}

Available upon request from the authors.

\section{Code availability}


Not applicable.

\section{Authors' contributions}

BLC: Project conception, design, data analysis, and manuscript preparation.

NAD: Project conception, design, data collection, data analysis, and manuscript preparation.

TLW: Data collection, data analysis, and manuscript preparation.

ECK: Data collection, data analysis, and manuscript preparation.

SEP: Data analysis, and manuscript preparation.

\section{Acknowledgments}

Funding for this project was provided by the U.S. Bureau of Reclamation's Central Valley Project Conservation Program, U.S. Fish and Wildlife Service, and the California Department of Fish and Wildlife. We thank Jaime Rudd, Larry Saslaw, and Christine Van Horn Job for assistance with data collection. We thank Jed Murdoch for early assistance with data analysis. We thank the many businesses and residents in Bakersfield, California who provided access to their properties for camera station surveys.

\section{References}

1. Adams CE, Lindsey KJ, Ash SJ (2006) Urban wildlife management. CRC Press, Boca Raton

2. Berry WH, Standley WG (1992) Population trends of San Joaquin kit fox at Camp Roberts Army National Guard Training Site, California. US Department of Energy Topical Report No. EGG 106172155, Springfield, VA

3. Boroski BB, Powers RM, Huizing MJ, Maher JD, Cypher BL, Westall TL, Kelly EC (2021) Response of endangered kit foxes to the California Valley Solar Ranch. In Cypher BL, Boroski BB, Meade DE, Westall TL, Powers RM, Spencer KA, Kelly EC, Huizing MJ, Maher JD, Dart J (eds). Response of endangered kit foxes to solar farms. Wildlife Monographs (submitted)

4. Bjurlin CD, Cypher BL, Wingert CM, Van Horn Job CL (2005) Urban roads and the endangered San Joaquin kit fox. California Department of Transportation, Endangered Species Recovery Program Final Report, Contract Number 65A0136, Fresno, California

5. Burnham KP, Anderson DR (2002) Model Selection and multimodal inference: a practical information theoretic, 2nd ed. Springer-Verlag, New York

6. Cade TJ, Martell M, Redig P, Septon G, Tordoff H (1996) Pergrine falcons in urban North America. In: Bird DM, Varland DE, Negro JJ (eds) Raptors in human landscapes. Academic Press, London, pp 313

7. Cypher BL (2010) Kit foxes. In Gehrt SD, Riley SP D, Cypher BL (eds). Urban carnivores: ecology, conflict, and conservation. Johns Hopkins University Press, Baltimore, pp. 49-60 
8. Cypher BL, SE Phillips, Kelly PA (2013) Quantity and distribution of suitable habitat for endangered San Joaquin kit foxes: conservation implications. Canid Biol Cons 16:25-31

9. Cypher BL, Rudd JL, Westall TL, Woods LW, Stephenson N, Foley JE, Richardson D, Clifford DL (2017) Sarcoptic mange in endangered kit foxes: case histories, diagnoses, and implications for conservation. J Wildlife Dis 53:46-53

10. Cypher BL, Van Horn Job CL (2012) Management and conservation of San Joaquin kit foxes in urban environments. Proc Vert Pest Conf 25:347-352

11. Cypher BL, Warrick GD, Otten MRM, O'Farrell TP, Berry WH, Harris CE, Kato TT, McCue PM, Scrivner JH, Zoellick BW (2000) Population dynamics of San Joaquin kit foxes at the Naval Petroleum Reserves in California. Wildlife Monographs 145:1-45.

12. Cypher BL, Westall TL, Van Horn Job CL, Kelly EC (2014) San Joaquin kit fox conservation in a satellite habitat area. California State University-Stanislaus, Endangered Species Recovery Program, Turlock, CA.

13. Deatherage NA, Cypher BL, Murdoch J, Westall TL, Kelly EC, Germano DJ (2021). Urban landscape attributes affect occupancy patterns of the San Joaquin kit fox during an epizootic. Pacific Cons Biol (in press)

14. Frankham R, Ballou JD, Ralls K, Eldridge MDB, Dudash MR, Fenster CB, Lacy RC, Sunnucks P (2017). Genetic management of fragmented animal and plant populations. Oxford Up Press, Oxford

15. Frost $N$ (2005) San Joaquin kit fox home range, habitat use, and movements in urban Bakersfield. Thesis, Humboldt St U, Arcata, CA

16. Germano DJ, Rathbun GB, Saslaw LR, Cypher BL, Cypher EA, Vredenburgh LM (2011) The San Joaquin desert of California: ecologically misunderstood and overlooked. Natural Areas J 31:138147

17. Gese EM, Bekoff M (2004) Coyote (Canis latrans). In Sillero-Zubiri C, Hoffman M, and Macdonald DW (eds). Canids: foxes, wolves, jackals and dogs: status survey and conservation action plan. International Union for Conservation of Nature and Natural Resources, Cambridge, UK, pp 81-87

18. Gosselink TE, Van Deelen TR, Warner RE, Mankin PC (2007) Survival and cause-specific mortality of red foxes in agricultural and urban areas of Illinois. J Wildlife Manage 71:1862-1873

19. Hines JE (2006) PRESENCE- Software to estimate patch occupancy and related parameters. https://www.mbrpwrc.usgs.gov/software/presence.html (accessed 1 September 2019)

20. Holmala K, Kauhala K (2006) Ecology of wildlife rabies in Europe. Mammal Rev 36:17-36

21. Johnson WE, Fuller TK, Franklin WL (1996) Sympatry in canids: a review and assessment. In Gittleman JL (ed). Carnivore behavior, ecology, and evolution. Cornell U Press, Ithaca, NY, pp 189-218

22. Kelly PA, Phillips SE, Williams DF (2005) Documenting ecological changes in time and space: the San Joaquin Valley of California. In Lacey EA, Myers $P$ (eds). Mammalian diversification: from chromosomes to phylogeography. U California Press, Berkeley, pp 57-78

23. Legendre P, Legendre L (1998) Numerical ecology, 2nd ed. Elsevier Science B.V., Amsterdam 
24. Macdonald DW, Reynolds J (2004) Red fox (Vulpes vulpes). In Sillero-Zubiri C, Hoffman M, and Macdonald DW (eds). Canids: foxes, wolves, jackals and dogs: status survey and conservation action plan. International Union for Conservation of Nature and Natural Resources, Cambridge, UK, pp 129-136

25. MacKenzie DI, Nichols JD, Royle JA, Pollock KH, Bailey LL, Hines JE (2018) Occupancy estimation and modeling, inferring patterns and dynamics of species occurrence, 2nd ed. Academic Press, San Diego

26. Marks CA, Bloomfield TE (1999) Distribution and density estimates for urban foxes (Vulpes vulpes) in Melbourne: implications for rabies control. Wildlife Res 26:763-775.

27. Nelson JL, Cypher BL, Bjurlin CD, Creel S (2007) Effects of habitat on competition between kit foxes and coyotes. J Wildlife Manage 71:1467-1475

28. National Oceanic and Atmospheric Administration (2020) National Weather Service, Bakersfield, California, Bakersfield monthly rainfall by water year 1889-present.

https://www.wrh.noaa.gov/hnx/bfl/normals/bflh2oyr.pdf (accessed 25 January 2021)

29. Rosatte RC, Power MJ, Maclnnes D (1990) Rabies control for urban foxes, skunks and raccoons. In Davis LR, Beadle DE (eds) Proceedings of the 14th Vertebrate Pest Conference. University of California, Davis, pp 160-167

30. de Smith MJ, Goodchild MF, Longley PA (2021) Geospatial analysis: a comprehensive guide to principles, techniques and software tools, $6^{\text {th }}$ ed.

https://www.spatialanalysisonline.com/HTML/index.html (accessed 12 August 2021)

31. Soulsbury CD, Baker PJ, lossa G, Harris S (2010) Red foxes (Vulpes vulpes). In Gehrt SD, Riley SP D, Cypher BL (eds). Urban carnivores: ecology, conflict, and conservation. Johns Hopkins University Press, Baltimore, pp. 63-75

32. Spiegel LK, Bradbury M (1992) Home range characteristics of the San Joaquin kit fox in western Kern County, California. Trans West Sect The Wildlife Soc 28:83-92

33. Uraguchi K, Ueno M, lijima H, Saitoh T (2014) Demographic analyses of a fox population suffering from sarcoptic mange. J Wildlife Manage 78:1356-1371

34. US Fish and Wildlife Service (1998) Recovery plan for upland species of the San Joaquin Valley, California. US Fish and Wildlife Service, Region 1, Portland

35. US Fish and Wildlife Service (2010) San Joaquin kit fox 5-year review: summary and evaluation. US Fish and Wildlife Service, Region 1, Portland

36. Voigt DR (1987) Red fox. In Novak M, Baker JA, Obbard ME, Malloch B (eds). Wild Furbearer Management and Conservation in North America. Ontario Ministry of Natural Resources, Ontario, CAN, pp 387-393

37. Voigt DR, Berg WE (1987) Coyote. In Novak M, Baker JA, Obbard ME, Malloch B (eds). Wild Furbearer Management and Conservation in North America. Ontario Ministry of Natural Resources, Ontario, CAN, pp 344-357 
38. Warrick GD, Clark HO, Jr., Kelly PA, Williams DF, Cypher BL (2007) Use of agricultural lands by San Joaquin kit foxes. West North Am Nat 67:270-277

39. Westall TL, Cypher BL (2017) Latency to first detection of kit foxes (Vulpes macrotis) during camera surveys. Canid Biol Cons 20:32-37

40. White PJ, Vanderbilt White CA, Ralls K (1996) Functional and numerical responses of kit foxes to a short-term decline in mammalian prey. $\mathrm{J}$ Mammal 77:370-376

41. Wilbert TR (2013) Patterns and processes of genetic diversity in the endangered San Joaquin kit fox. Dissertation, George Mason U, Fairfax, VA

\section{Tables}

Table 1 Covariates used in candidate occupancy models for urban San Joaquin kit foxes in Bakersfield, California in 2015.

Covariate Description

High Highways: conducts vehicular traffic into and out of the city

HighwayR Provides vehicular access onto or off of highways

ArterialR Arterial roads: one to three lanes of vehicular traffic in each direction, connects local and collector roads to highways

CollectorR Collector roads: connects local roads to arterial roads, may provide vehicular access to residential property or businesses

$R R \quad$ Railroads

LocalR Local roads: provides vehicular access to residential property

OROW Other vehicular rights-of-way: unspecified frequency of vehicular traffic, e.g., parking lots, dirt roads, alleyways, etc.

PGS Parks and green spaces: recreational areas, golf courses, cemeteries, large lawns, etc.

LMDR Low to medium density residential areas: apartment homes, nursing homes, and townhomes

Camp Campuses: schools, churches, and large medical centers

Com Commercial areas: office buildings, hotels, shopping centers, restaurants, etc.

Tree $\quad$ Mature tree cover

Water Source with water consistently present

Table 2 Model selection results for supported occupancy models and the global model for San Joaquin kit foxes in Bakersfield, California in 2015. Habitat attribute covariates are defined in Table 1. 


\begin{tabular}{|c|c|c|c|c|c|}
\hline Model name & K & $\mathrm{QAIC}_{\mathrm{c}}$ & $\triangle \mathrm{QAIC}_{\mathrm{c}}$ & $w$ & $-2 *$ LogLike \\
\hline psi(.),p(varies) & 9 & 304.22 & 0.00 & 0.04 & 767.11 \\
\hline psi(High),p(varies) & 10 & 304.36 & 0.13 & 0.04 & 761.83 \\
\hline $\mathrm{psi}(P G S), \mathrm{p}$ (varies) & 10 & 305.42 & 1.19 & 0.02 & 764.66 \\
\hline $\mathrm{psi}(L M D R), \mathrm{p}$ (varies) & 10 & 305.58 & 1.35 & 0.02 & 765.09 \\
\hline psi(Tree),p(varies) & 10 & 305.58 & 1.35 & 0.02 & 765.10 \\
\hline psi(Camp),p(varies) & 10 & 305.59 & 1.36 & 0.02 & 765.12 \\
\hline psi(CollectorR+High),p(varies) & 11 & 305.61 & 1.38 & 0.02 & 759.49 \\
\hline $\mathrm{psi}($ CollectorR),p(varies) & 10 & 305.67 & 1.44 & 0.02 & 765.35 \\
\hline $\mathrm{psi}($ High+LMDR),p(varies) & 11 & 305.85 & 1.62 & 0.02 & 760.13 \\
\hline $\mathrm{psi}($ High+PGS),p(varies) & 11 & 305.90 & 1.67 & 0.02 & 760.26 \\
\hline psi(Tree+High),p(varies) & 11 & 305.90 & 1.67 & 0.02 & 760.26 \\
\hline psi(ArterialR),p(varies) & 10 & 305.95 & 1.72 & 0.02 & 766.10 \\
\hline psi(High+Camp),p(varies) & 11 & 306.04 & 1.81 & 0.02 & 760.65 \\
\hline $\mathrm{psi}($ ArterialR+High),p(varies) & 11 & 306.06 & 1.83 & 0.02 & 760.70 \\
\hline psi(Camp+PGS),p(varies) & 11 & 306.86 & 2.63 & 0.01 & 762.85 \\
\hline $\mathrm{psi}($ CollectorR+PGS),p(varies) & 11 & 306.91 & 2.68 & 0.01 & 762.99 \\
\hline $\mathrm{psi}($ CollectorR+Camp),p(varies) & 11 & 307.00 & 2.77 & 0.01 & 763.22 \\
\hline psi(global),p(varies) & 14 & 310.70 & 6.48 & 0.00 & 755.91 \\
\hline
\end{tabular}

Table 3 Model-averaged parameter estimates with 95\% confidence intervals for supported occupancy models for San Joaquin kit foxes in Bakersfield, California in 2015. Habitat attribute parameters are defined in Table 1. 


\begin{tabular}{llll} 
Parameter & $\beta$ & Lower $\mathrm{Cl}$ & Upper Cl \\
\hline$\psi$ & 0.62 & -0.08 & 1.33 \\
\hline High & -0.24 & -0.47 & -0.01 \\
\hline PGS & 0.06 & -0.03 & 0.16 \\
\hline LMDR & 0.07 & -0.04 & 0.17 \\
\hline Tree & 0.03 & -0.02 & 0.08 \\
\hline Camp & 0.03 & -0.03 & 0.09 \\
\hline CollectorR & -0.08 & -0.20 & 0.04 \\
\hline ArterialR & -0.05 & -0.15 & 0.05 \\
\hline$p 1$ & 0.05 & -0.05 & 0.15 \\
\hline$p 2$ & 0.01 & -0.02 & 0.04 \\
\hline$p 3$ & -0.02 & -0.06 & 0.03 \\
\hline$p 4$ & -0.02 & -0.07 & 0.03 \\
\hline$p 5$ & -0.01 & -0.05 & 0.02 \\
\hline$p 6$ & -0.02 & -0.08 & 0.03 \\
\hline$p 7$ & -0.05 & -0.15 & 0.05
\end{tabular}

Table 4 San Joaquin kit fox habitat classifications defined by occupancy probability values ( $\psi$ range), and the total number of $1-\mathrm{km}^{2}$ grid cells with occupancy probability values for each habitat classification in Bakersfield, California in 2015.

\begin{tabular}{lll} 
Habitat classification & $\psi$ range & No. of cells \\
\hline High & $0.23-0.25$ & 121 \\
\hline Medium & $0.21-0.22$ & 196 \\
\hline Low & $0.13-0.20$ & 40
\end{tabular}

Table 5 Number of $1-\mathrm{km}^{2}$ grid cells surveyed each year with automated camera stations, number of cells with San Joaquin kit fox detections, number of foxes detected, and population estimate for a $357-\mathrm{km}^{2}$ study area in Bakersfield, California. "Ad" = adult and "Juv" = juvenile. 


\begin{tabular}{llllllllllll} 
& & \multicolumn{3}{c}{ Cells with foxes } & \multicolumn{3}{c}{ Number of foxes } & \multicolumn{3}{c}{ Population estimate } \\
\hline Year & Cells sampled & Total & Ad & Juv & Total & Ad & Juv & Total & Ad & Juv \\
\hline 2015 & 105 & 68 & 66 & 13 & 129 & 112 & 17 & 439 & 381 & 58 \\
\hline 2016 & 111 & 52 & 51 & 7 & 94 & 82 & 12 & 302 & 264 & 39 \\
\hline 2017 & 109 & 39 & 38 & 10 & 82 & 68 & 14 & 269 & 223 & 46 \\
\hline 2018 & 111 & 29 & 28 & 8 & 52 & 41 & 11 & 167 & 132 & 35 \\
\hline 2019 & 110 & 23 & 23 & 7 & 43 & 33 & 10 & 140 & 107 & 32
\end{tabular}

\section{Figures}

2

Figure 1

Location of $1051-\mathrm{km} 2$ grid cells surveyed for San Joaquin kit foxes out of 357 grid cells covering the city of Bakersfield, California in 2015.

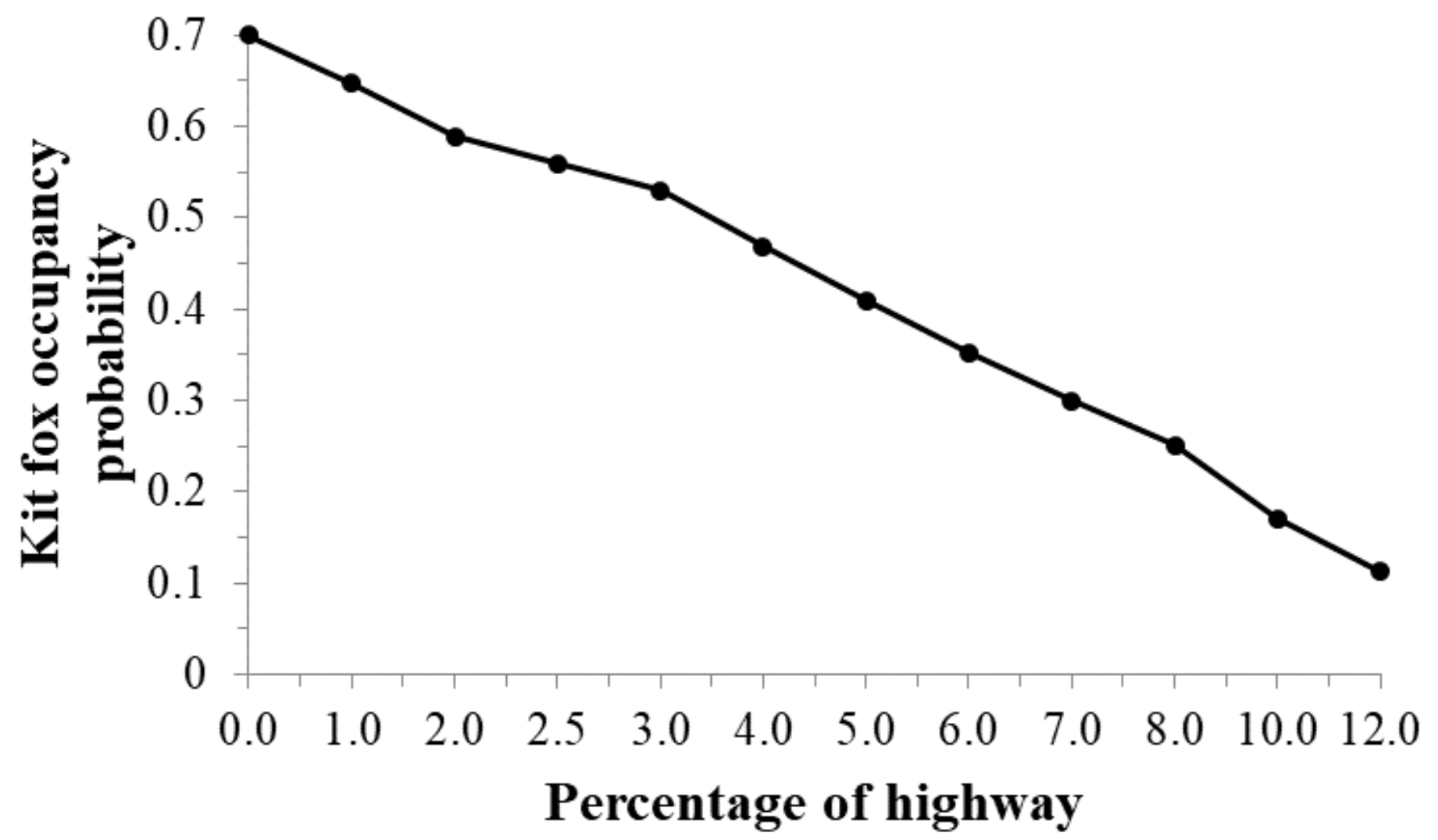

Figure 2 
San Joaquin kit fox occupancy probability estimates as a function of percentage of highway roads within 1-km2 grid cells in Bakersfield, California in 2015.

娄

\section{Figure 3}

San Joaquin kit fox habitat classifications defined by modeled occupancy probability values for 357 1km2 grid cells in Bakersfield, California in 2015.

证

\section{Figure 4}

San Joaquin kit fox occupancy probability as a function of urban landscape characteristics in Bakersfield, California in 2015. The distribution of $1-\mathrm{km} 2$ grid cells with $\geq 10 \%$ open space (parks and green spaces, campuses, low-medium residential) is superimposed. 